\title{
A REDE FEDERAL DE EDUCAÇÃO E SUA EXPANSÃO NO RIO GRANDE DO NORTE: UMA ANÁLISE DO CAMPUS DO IFRN NA CIDADE DE JOÃO CÂMARA/RN
}

\author{
M. P. BARRETO \\ Instituto Federal de Educação, Ciência e Tecnologia do Rio Grande do Norte \\ Mestrando em Arquitetura e Urbanismo - UFRN \\ marciobarretojc@gmail.com
}

Artigo submetido em fevereiro/2013 e aceito em agosto/2014

DOI: 10.15628/holos.2014.1261

\begin{abstract}
RESUMO
Este artigo é fruto do trabalho de conclusão de curso intitulado A Expansão dos Institutos Federais no Rio Grande do Norte: Desafios e Perspectivas do campus na cidade de João Câmara/RN. Teve o objetivo de analisar a estruturação dos cursos, suas correlações com os arranjos produtivos locais e como vem se desenvolvendo o fator da empregabilidade dos alunos egressos. Devido à ausência de mais estudos sobre a área de estudo e a temática, houve a necessidade de se estudar a realidade local. Para tanto foram utilizadas bibliografias pertinentes à temática, dados do IBGE, DIEESE, entrevista com estudantes do Instituto Federal e também com Gestores do IFRN. Os estudos sobre os cursos do Instituto e a interligação destes com os arranjos produtivos locais
\end{abstract}

trouxeram substanciais contribuições para a formulação do trabalho em tela, haja vista que esta instituição representa uma grande mudança na realidade do município. A luz de alguns autores e documentos governamentais, acompanhamos as mudanças pelas quais o IFRN campus João Câmara vem causando e como o município sofreu tais impactos e mudanças nos âmbitos socioeconômicos e territoriais. Verificou-se a partir do embasamento teórico como diversos atores políticos e sociais que de fato os impactos provenientes da edificação do Instituto Federal no município vêm acontecendo com rapidez, mas ainda em seu início, bem como a inserção dos alunos egressos no mercado de trabalho, onde as oportunidades ainda são poucas.

PALAVRAS-CHAVE: João Câmara/RN, Expansão, IFRN, Rio Grande do Norte, Educação Profissional.

\section{FEDERAL EDUCATION NETWORK AND ITS EXPANSION IN RIO GRANDE DO NORTE: AN ANALYSIS OF THE IFRN CAMPUS IN THE CITY OF JOÃO CÂMARA/RN}

\begin{abstract}
This article is the work of completion titled The Expansion of the Federal Institutes in Rio Grande do Norte: Challenges and Prospects campus in the city of João Câmara / RN. Had the objective of analyzing the structure of the courses, their correlations with local production and as has been developing the employability factor of students graduates. Due to the absence of further studies on the study area and the theme, there was a need to study the local reality. Therefore, we used bibliographies relevant to the topic, the IBGE, DIEESE, interview with the students and also with the Federal Managers IFRN. Studies of the Institute courses and linking these with the local productive arrangements brought substantial
\end{abstract}

contributions to the formulation of screen work, considering that this institution represents a major shift in the reality of the municipality. The light of other authors and government documents, follow the changes that the campus IFRN João Câmara has caused and how the city suffered such impacts and changes in socioeconomic and territorial scopes. It was found from the theoretical as various social and political actors that actually impacts from the Federal Institute building in the municipality have been going fast, but still in its beginning as well as the inclusion of students graduates in the labor market, where opportunities are still few.

KEYWORDS: João Câmara/RN, Expansion, IFRN, Rio Grande do Norte, Professional Education. 


\section{INTRODUÇÃO}

O presente estudo contempla os resultados das atividades desenvolvidas no âmbito da pesquisa "A expansão dos Institutos Federais no Rio Grande do Norte: Desafios e Perspectivas do campus na cidade de João Câmara/RN". A referida análise teve como intuito investigar a dinâmica socioeconômica e territorial advinda da construção do Campus do Instituto Federal de Educação, Ciência e Tecnologia do Rio Grande do Norte na cidade de João Câmara/RN, com o objetivo de analisar a estruturação dos cursos, suas correlações com os arranjos produtivos locais e como vem se desenvolvendo o fator da empregabilidade dos alunos egressos.

O que motivou a referida pesquisa foi a importância das transformações socioeconômicas e territoriais que a implementação do Campus João Câmara vem promovendo desde a sua construção, quer seja através dos cursos oferecidos, através de ações voltadas para com a comunidade local e regional e por toda transformação e valorização proporcionada.

A construção do Campus de João Câmara faz parte da 2a Fase do Plano de Expansão da Rede Federal de Educação Profissional e Tecnológica do Ministério da Educação, iniciada em 2007, constituindo-se um dos enfoques da atual política do Plano de Desenvolvimento da Educação (PDE) do país.

O Rio Grande do Norte, como parte dessa fase, foi contemplado com a construção de 6 (seis) Unidades do Instituto Federal de Educação, Ciência e Tecnologia do Rio Grande do Norte (IFRN), os quais passaram a funcionar em cidades-pólos nos municípios de Apodi, Caicó, João Câmara, Macau, Pau dos Ferros, Santa Cruz, Parnamirim, São Gonçalo do Amarante e Nova Cruz. Atualmente existe uma nova etapa de expansão onde o estado receberá mais 3 campi: Ceará Mirim, São Paulo do Potengi e Canguaretama.

Como recorte espacial da pesquisa, fizemos a opção pelo município de João Câmara, o qual concentra em seu redor os municípios de Bento Fernandes, Poço Branco, Parazinho e Jandaíra, formando a denominada microrregião de Baixa Verde. Outras cidades também se concentram ao redor de João Câmara, como São Bento do Norte, Taipú, São Miguel do Gostoso, Pedra Grande, Caiçara do Norte e Jardim de Angicos. Além disso, o município ainda é polarizador de serviços essenciais para os habitantes da região, tais como bancos, hospital, clínicas, escolas, universidades, entre outros diversos serviços.

As principais atividades econômicas do município giram em torno da agropecuária, do extrativismo, do setor terciário e do setor informal. Portanto, os cursos escolhidos para funcionarem no Campus João Câmara estão em sintonia com grande parte das potencialidades locais e regionais. Assim, funcionam nas modalidades PROEJA (Programa Nacional de Integração da Educação Profissional), Subsequente e Técnico Integrado, os cursos de Cooperativismo, de Informática, e de Eletrotécnica. Além destes, funcionam ainda os cursos superiores de Licenciatura em Física e o de Tecnologia em Energias Renováveis.

Diante desse quadro de referência, algumas questões serviram de eixo norteador para a nossa pesquisa, tais como: quais os principais impactos que a instalação do Campus João Câmara vem promovendo e promoverá na microrregião de Baixa Verde/RN, quanto aos aspectos socioeconômicos e territoriais? Até que ponto os estudantes egressos irão conseguir ser absorvidos pelo mercado de trabalho local e microrregional? Como o poder público e o setor 
produtivo local irão absorver essa mão de obra qualificada? Quais os principais desafios e perspectivas que a chegada do Campus do IFRN na cidade de João Câmara trará para o município? Para responder a estes questionamentos, durante toda a pesquisa, nos utilizamo-nos de visitações e pesquisas in loco, bem como de entrevistas semi estruturadas e informais. Em suma, esta pesquisa qualitativa faz uso da análise visual de aspectos materiais, como por exemplo, de suportes cartográficos para justificar as observações realizadas. Além disso, o suporte oral possibilita à pesquisa a análise de aspectos que não são facilmente identificados em estatísticas ou em mapas da cidade.

Dessa maneira, buscou-se nesta pesquisa elaborar um estudo que possa ser requisitado por todos, desde alunos e professores, bem como por órgãos públicos da região (prefeituras e secretarias), fazendo com que sirva de embasamento para posteriores estudos na área de abrangência da pesquisa, como também na formulação e implementação de políticas públicas que visem o desenvolvimento e crescimento econômico e social da cidade de João Câmara e dos municípios vizinhos.

Destarte, podemos inferir que é um estudo que visa resultados a médio e longo prazo, uma vez que as transformações ocorridas na cidade de João Câmara e na microrregião de Baixa Verde, a nosso ver, começaram, em um primeiro momento, com a implantação do campus na cidade e que continuará acontecendo ao longo do período de funcionamento do IFRN no município. Nesse contexto, nosso estudo se torna um instrumento de análise e consulta para toda a população e demais interessados, podendo influenciar futuras pesquisas na área, assim como contribuir para a construção de um arcabouço teórico acerca da temática.

O presente estudo é estruturado além da introdução, por mais 4 sessões, além das considerações finais. Na segunda sessão, A "Capital do mato grande" João Câmara/RN, apresentamos uma caracterização da cidade de João Câmara, como forma de contextualizar nosso recorte espacial de pesquisa. Em seguida, apresentaremos a sessão três: $A$ expansão dos Institutos Federais de Educação, Ciência e Tecnologia no Rio Grande do Norte, onde será explanada a expansão dos institutos federais no estado. Na sessão quatro, A implementação do Instituto Federal em João Câmara/RN, buscaremos dar um panorama de como ocorreu a implementação do IFRN no municipio, analisando os cursos e suas relações com as potencialidades locais e regionais. A última sessão Fatores de dificuldade: a inserção do egresso no mercado de trabalho traz uma discussão a respeito das oportunidades de estágio e o fator empregabilidade para os alunos egressos do Instituto Federal localizado em João Câmara. Por fim, as considerações finais trarão as nossas indagações e sugestões de acordo com o estudo realizado.

\section{A “CAPITAL DO MATO GRANDE" JOÃO CÂMARA/RN}

O município de João Câmara localiza-se na microrregião da Baixa Verde, a qual se insere na área territorial da mesorregião Agreste Potiguar. Limita-se territorialmente a Norte - Parazinho e Touros, a Sul - Bento Fernandes, a Leste - Touros, Pureza e Poço Branco e a Oeste - Jandaíra e Jardim de Angicos. 


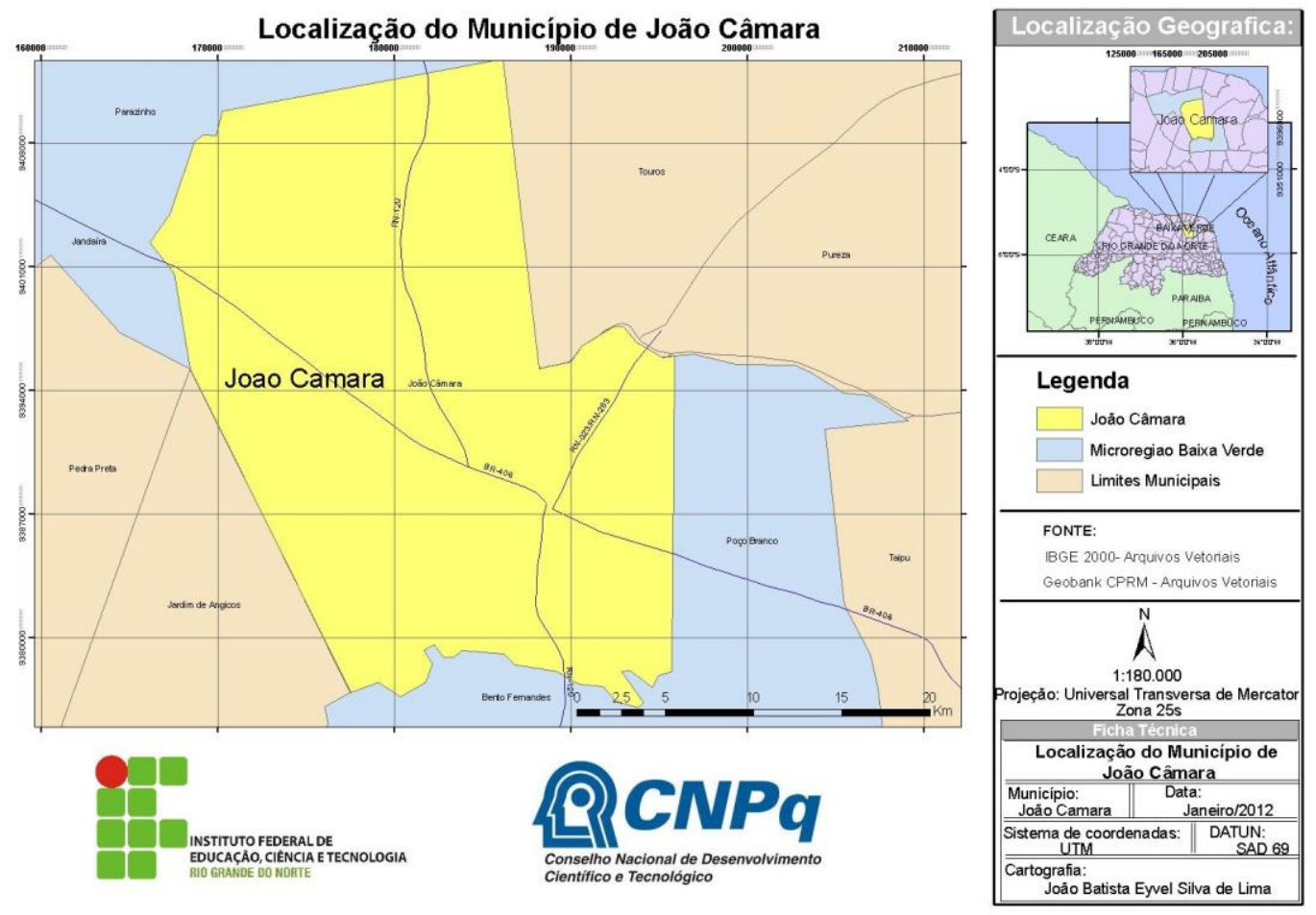

Figura 1 - Localização do município de João Câmara

Fonte: Elaborado por João Batista Eyvel Silva Lima, 2012.

O então município de João Câmara foi Distrito criado pela lei municipal no 2, de 22-12-1892, com a denominação de Baixa Verde, sendo subordinado ao município de Taipu. Foi desmembrado de Touros, Lajes e Taipú, por força da Lei $n^{\circ} 697$, de 29/10/1928. Inicialmente se chamava Matas, em seguida chamou-se Baixa Verde e por fim, teve seu nome mudado pela Lei $n^{\circ} 899$, de 19/11/1953, para a atual nomenclatura João Câmara. (IBGE, 2010)

A área espacial de João Câmara abrange um total de $715 \mathrm{~km}^{2}$, o que equivale a mais ou menos $1,75 \%$ da superfície estadual. Até década de 1970, a população da cidade ainda era em sua majoritariamente rural, mas na década de 1980 há um salto no percentual da população urbana sobre a do campo, na qual a primeira passa a ser maior. Um dos motivos para tal virada foi o enfraquecimento e, de certo modo, a falência de algumas economias tradicionais e a reestruturação urbana e comercial pela qual a cidade estava passando. Com isso, a população camponesa começou a ir em direção ao centro urbano em busca de trabalho e melhores condições de vida. Na figura 2 observamos, com bases nos censos demográficos do IBGE da década de 1940 até o último em 2010, como foi a evolução populacional do município, nos últimos 70 anos. 


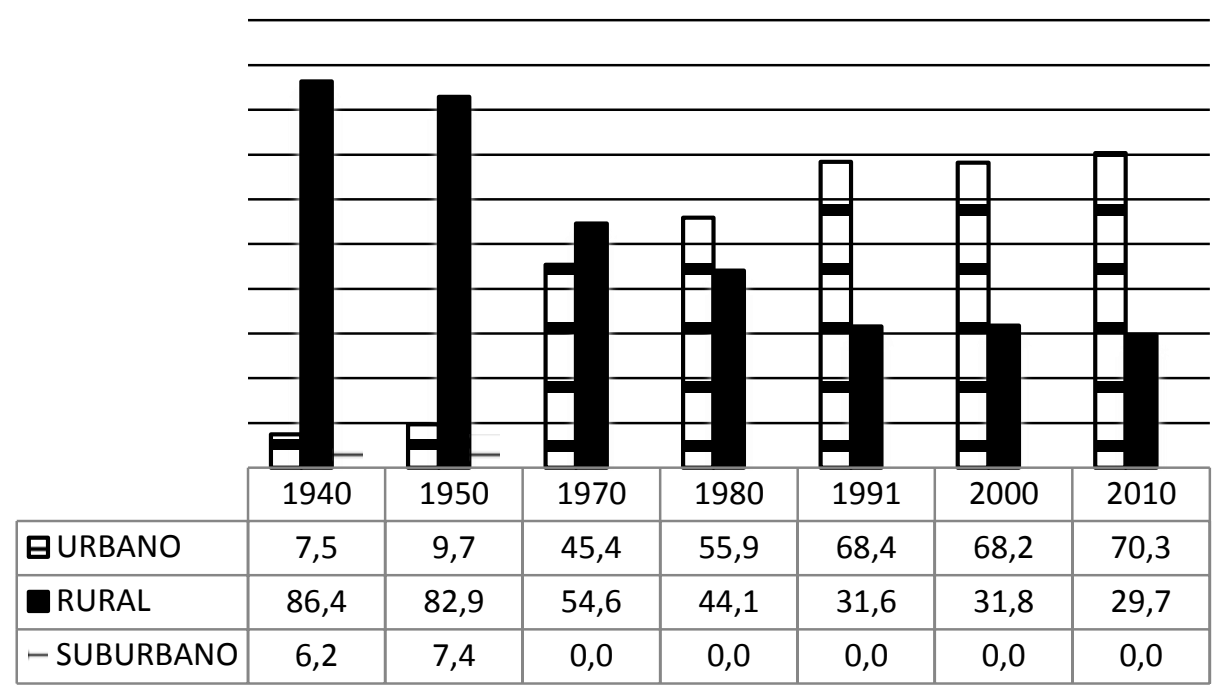

Figura 2 - Evolução populacional de João Câmara

Fonte: Adaptado e editado de Souza e Silva (2006) com dados do IBGE (2010).

Conforme podemos observar, existe uma lacuna no gráfico referente a informações da década de 1960, uma vez que o Censo dessa década não disponibiliza informações a respeito da população urbana e rural da cidade de João Câmara ${ }^{1}$.

Outro ponto importante é que a partir da década de 1980 a maioria da população passou a ser urbana. Isso se deve em grande parte ao fato de alguns serviços públicos essenciais chegarem à sede do município, como água encanada, energia elétrica em quase todos os bairros, pavimentação e melhoria das habitações, atraindo as pessoas que antes moravam no campo a viverem na cidade, devido às melhores condições de vida oferecidas. Com isso, essa migração contínua para o centro urbano, contribuiu para que essa superioridade viesse se mantendo até os dias atuais. Atualmente, a predominância do urbano sobre o rural vem ficando cada vez mais evidente em decorrência do fluxo cada vez maior de pessoas do campo para a cidade. Haja vista o crescimento da oferta de serviços em virtude do próprio processo de urbanização e implementação de investimentos governamentais, os quais acabam impactando setores como, por exemplo, o econômico.

Em relação à economia local, o setor terciário em João Câmara teve e tem grande importância na dinâmica econômica e social municipal, gerando emprego e renda, conforme anteriormente pontuado. Nesse viés, corroboramos com Oliveira (1987, p. 53), quando aponta que "(...) o terciário se caracteriza como um setor gerador de bens imateriais (serviços em específico) e da realização (distribuição, circulação e venda) de bens materiais de outros setores". Ou seja, o terciário pode ser dividido em duas categorias específicas: a prestação de serviços e o comércio em geral. No que se refere a João Câmara, o comércio foi e é um elemento que contribuiu substancialmente na vida econômica do município, pois em diferentes momentos de sua história, foi este que regeu as relações econômicas. Com base em dados do IBGE (2010), constatou-se que o município possui cerca de 503 empresas atuantes entre comércios variados e grandes empresas, empregando formalmente 2.622 pessoas, sendo que, grande parcela desse quantitativo está empregada no funcionalismo público. Mesmo com esse expressivo número de empresas, ainda não há uma oferta certa de estágios para os alunos do IFRN. Nesse sentido, trazemos também

\footnotetext{
${ }^{1}$ Nos relatórios do IBGE da época pesquisados não existe nenhum dado referente aos anos de 1960.
} 
dados do Ministério do Trabalho e Emprego (tabela 1) os quais mostram a distribuição de empregos por área no município.

Tabela 1 - Distribuição de vagas de emprego por área em João Câmara/RN

\begin{tabular}{|cc|}
\hline ÁREA & VAGAS \\
\hline Extrativismo mineral & 1 \\
Indústria de Transformação & 2 \\
Construção Civil & 12 \\
Comércio & 6 \\
Serviços & 2 \\
\hline
\end{tabular}

Fonte: CAGED/MTE, 2011.

As informações mostradas acima são do mês de março do ano de 2011, onde até então 23 empregos haviam sido gerados, com destaque para a construção civil, que com o aumento do número de pessoas na cidade (sejam estudantes, funcionários do IFRN ou trabalhadores dos parques eólicos) teve certo reaquecimento. Vale salientar que os empregos mostrados na tabela foram os gerados com carteira assinada, pois os dados referentes ao setor informal não foram disponibilizados ou encontrados, porém, se tem a ideia, a partir do que foi observado na cidade, que esse setor absorve uma parcela dos desempregados, gerando emprego e renda nesse município. A informalidade atinge desde jovens, até idosos, que veem esse campo como uma forma de sustento da família. Nesse sentido, João Câmara tem um papel importante no contexto da microrregião de Baixa Verde e na região do Mato Grande, haja vista a função polarizadora e de concentração de serviços essenciais para os moradores de tais localidades. Estes serviços apresentam-se na forma de supermercados, bancos, clínicas médicas e odontológicas, hospital público regional, postos de saúde públicos, escritórios de advocacia e contabilidade, empresas corretoras de imóveis, educação pública (Instituto Federal, Universidade Estadual do Rio Grande do Norte e escolas da rede municipal e estadual em nível fundamental e médio), educação privada (Universidade do Vale do Acaraú, Colégio Objetivo Potiguar, Escola Vovó Mulata, Jardim Escola Educativo, Escola Professor Júnior de jardim de infância e ensino fundamental) e nesse viés também se inserem os cursinhos preparatórios para o vestibular como o Univest, o Soberano e o Simetria (figura 3).

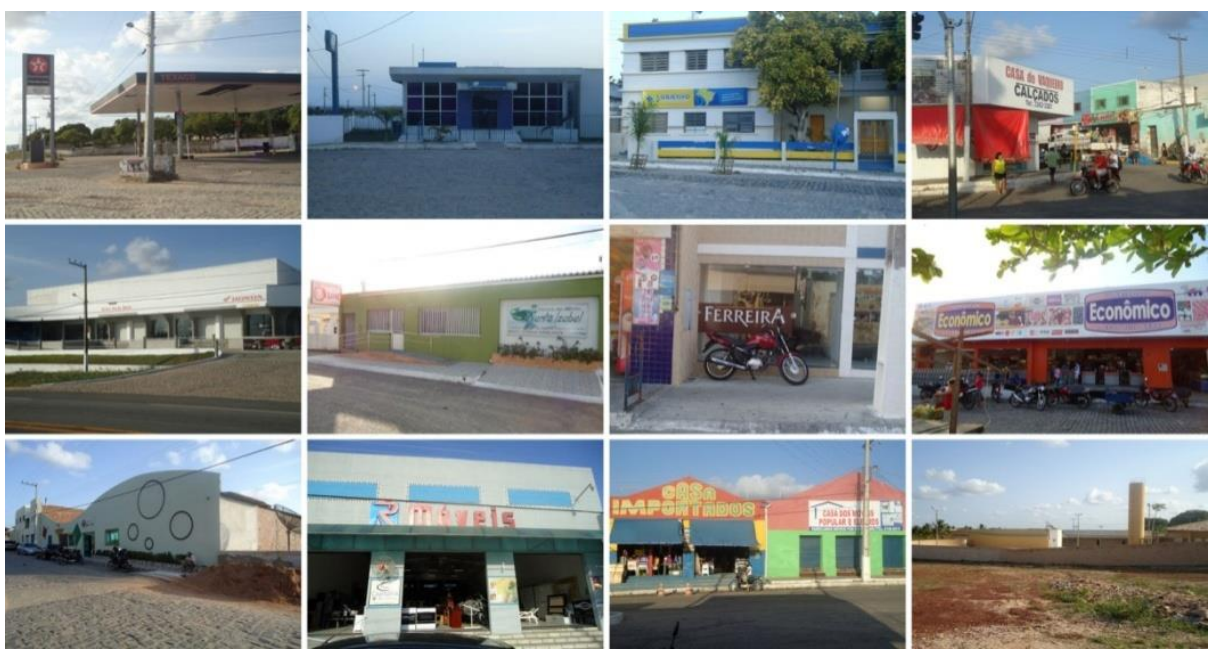

Figura 3 - Variedade de comércios e serviços na cidade polo de João Câmara Fonte: Barreto, 2012. 
Conforme observado na figura, percebemos que existe uma grande diversidade de atividades em João Câmara, as quais geram lucro para o município, fazendo com que o "carro chefe" do crescimento econômico continue sendo o terciário. Mesmo antes de sua emancipação política, era evidente (pois vários comércios se instalaram na cidade) a importância dessa atividade na economia local. Com a criação do município, começa uma fase de crescimento econômico atrelado a dois elementos: a Estrada de Ferro Central do Rio Grande do Norte e o crescente cultivo do algodão que traziam grande impulso à economia local.

No entanto, nas últimas décadas, esse município tem passado por mudanças importantes as quais vêm acompanhando, de certo modo, as características do atual processo mundial de globalização: inserção do global no local, mundialização da produção e comercialização, com a instalação de lojas de grande porte de empresas como Honda, Yamaha e Shineray.

Atualmente a cidade de João Câmara passa por uma nova "onda" de possibilidades de desenvolvimento, onde ocorre uma expansão das atividades produtivas relacionadas à energia eólica, que surge como o grande agente dinamizador e modelador das relações econômicas e sociais do espaço urbano e rural, conforme anteriormente pontuado.

Na próxima sessão buscaremos fazer uma abordagem da expansão da rede federal de educação tecnológica a nível estadual, ou seja, no Rio Grande do Norte.

\section{A EXPANSÃO DOS INSTITUTOS FEDERAIS DE EDUCAÇÃO, CIÊNCIA E TECNOLOGIA NO RIO GRANDE DO NORTE}

A história do Instituto Federal de Educação, Ciência e Tecnologia no Rio Grande do Norte, bem como sua expansão no estado, tem início em 23 de setembro de 1909, com outras nomenclaturas e estruturações pedagógicas. Deste modo, foi instalada em janeiro de 1910, a Escola de Aprendizes Artífices, que oferecia curso primário, curso de desenho e oficinas de trabalhos manuais. A mudança de denominação para Liceu Industrial de Natal integrou a reforma instituída pela Lei n.o 378, de 13/01/1937, do Ministério da Educação e Saúde, a quem as Escolas de Aprendizes Artífices estavam subordinadas desde o ano de 1930. Seguindo a ordem cronológica, no ano de 1942, o Liceu recebe a denominação de Escola Industrial de Natal, passando assim a atuar, vinte anos depois, na oferta de cursos técnicos de nível médio, e transformando-se, em 1965, em Escola Industrial Federal.

Com a inauguração da sua nova sede, no bairro do Tirol, a escola transfere-se em 1967 para as instalações onde hoje funciona o Campus Natal-Central do IFRN, recebendo, no ano seguinte, em 1968, a denominação de Escola Técnica Federal do Rio Grande do Norte. Entretanto, com o passar dos anos, a ETFRN extingue os cursos industriais básicos e passa a concentrar-se no ensino profissionalizante de 20 grau. Em 1994, inicia-se o processo onde em 1999, a ETFRN transforma-se em Centro Federal de Educação Tecnológica (CEFET). Nessa nova estruturação, os desafios incluiriam a oferta de educação profissional nos níveis básico, técnico e tecnológico, além do ensino médio (sua atuação no ensino de 3ำ grau começou com a oferta de cursos de graduação tecnológica, ampliando-se, em seguida, para os cursos de licenciaturas). Atualmente, o instituto passou a atuar também em outras ramificações da educação profissional, vinculando-se ao ensino médio na modalidade de educação de jovens e adultos e no ensino à distância, fortificando assim as redes de relações educacionais entre as várias etapas da vida acadêmica de seus discentes. 
A expansão propriamente dita da educação tecnológica federal no Rio Grande do Norte teve início em 1994 com a inauguração da Unidade de Ensino Descentralizada de Mossoró (a pioneira no processo de interiorização das ações do que na época era CEFET-RN). Com isso, doze anos depois ocorre uma nova etapa, fazendo com que mais alunos tivessem acesso ao ensino médio técnico. O Ministério da Educação, por meio da Secretaria de Educação Profissional e Tecnológica (SETEC), investiu na ampliação da atuação da rede no Estado, implantando, em meados de 2006, as unidades de Ensino da Zona Norte de Natal, de Ipanguaçu e de Currais Novos. Dessa forma, a expansão já tinha uma abrangência em parte do Seridó, Vale do Açu e região de Mossoró.

Nessa conjuntura, no ano de 2007, entra em ação a segunda etapa do Plano de Expansão da Rede, na qual o Rio Grande do Norte passa a contar com outras seis unidades, que foram inauguradas em 2009, os quais passaram a funcionar nas cidade-polo de Apodi, Pau dos Ferros, Macau, João Câmara, Santa Cruz e Caicó. Portanto, a distribuição desses institutos no território norteriograndese, deu-se em grande parte nas cidades polo de determinadas regiões, seja por suas potencialidades ou por grau de influência.

A partir de 2009, a instituição passa por uma nova transformação, onde passa a configurarse como o Instituto Federal de Educação, Ciência e Tecnologia do Rio Grande do Norte, originado pela lei n.o 11.892, de 29/12/2008. O objetivo desse novo modelo de instituição consiste em

\footnotetext{
"[...] ser a síntese daquilo que de melhor a Rede Federal construiu ao longo de sua história e das políticas de educação profissional e tecnológica do governo federal. Caracterizados pela ousadia e inovação necessárias a uma política e a um conceito que pretendem antecipar aqui e agora as bases de uma escola contemporânea do futuro e comprometida com uma sociedade radicalmente democrática e socialmente justa". (PACHECO, 2011, p.12)
}

Nesse sentido, percebemos que a abrangência das ações dos IF's engloba o compromisso de intervenção em suas respectivas regiões, identificando problemas e criando soluções técnicas e tecnológicas para o desenvolvimento sustentável. Também no ano de 2009, o Ministério da Educação autoriza a construção de mais 3 (três) novas unidades de ensino nos municípios de Nova Cruz, Parnamirim e São Gonçalo do Amarante, deixando o IFRN com 15 Campi, além do polo de Educação à Distância. Atualmente, há uma nova etapa do plano de expansão em curso onde o estado receberá mais 3 (três) campi: Ceará Mirim, São Paulo do Potengi e Canguaretama. Dessa forma, em apenas seis anos, a Instituição passa de duas unidades de ensino (Natal e Mossoró), para dezesseis unidades, atendendo as principais cidades polo do nosso Estado, como podemos observar na figura 4. 


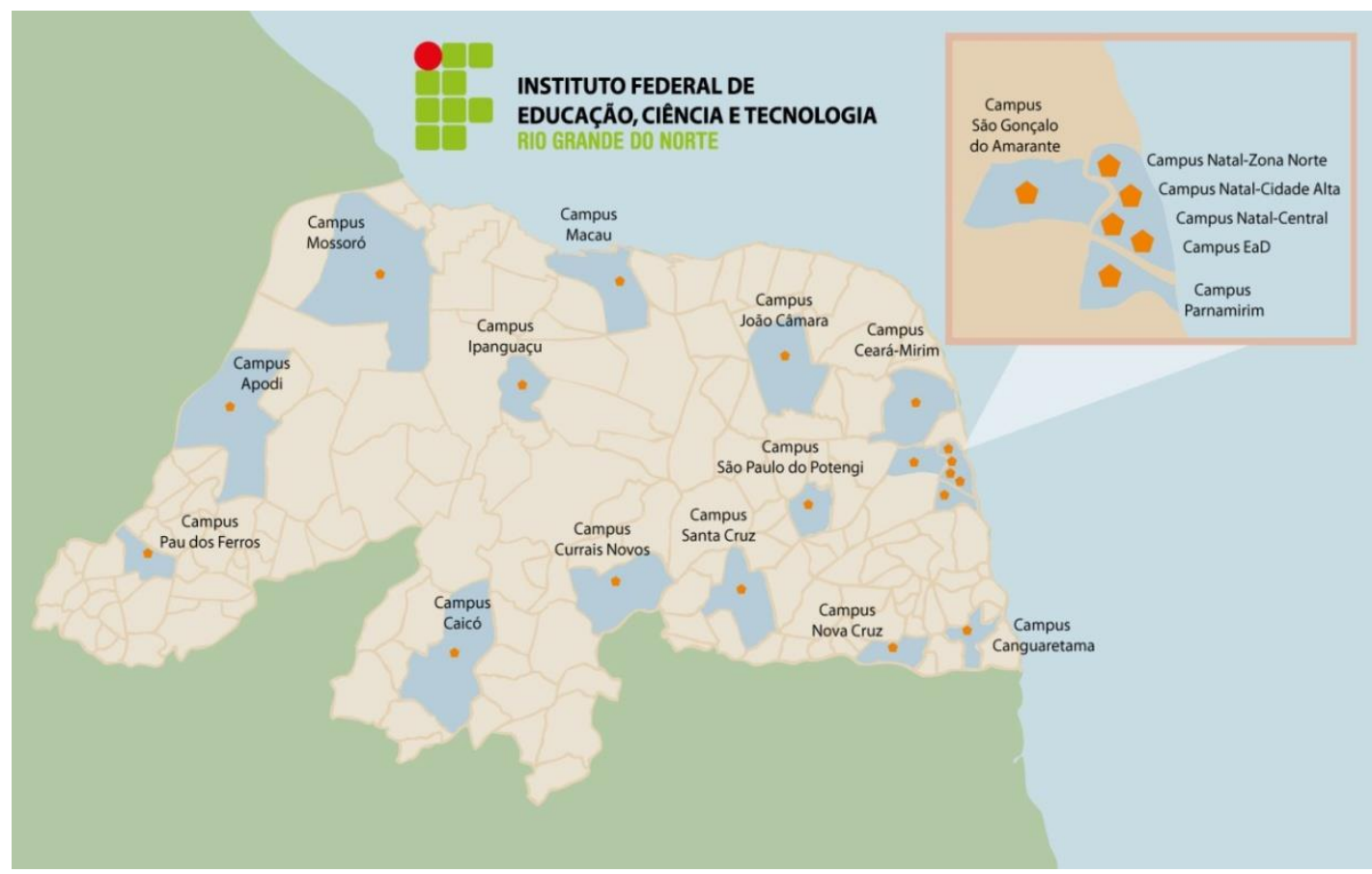

Figura 4 - Distribuição geográfica dos campi do IFRN no Rio Grande do Norte Fonte: IFRN, 2012.

Com base na figura a cima pode-se perceber que todas as mesorregiões potiguares estão atendidas com a distribuição territorial dos Institutos Federais, advindos da expansão da rede federal de educação tecnológica. Uma nova expansão está sendo elaborada no Rio Grande do Norte, e inicia-se em 2013 com a autorização para a implementação de dois novos Campi: Parelhas e Lajes (este encontra-se no mapa no ponto mais vazio, ou seja a região central do Estado). Outro ponto que é importante salientar é o modelo de expansão que ao nosso ver segue a linha das regiões de influência das cidades do IBGE, onde, de certa forma, todos os Institutos do estado se interligam ao Campus Natal Central em uma rede de qualificação profissional. Segundo dados do SISTEC (2012), no mês de junho os IF's possuíam 33.678 alunos matriculados em todo o estado, representando assim, um total de $18,75 \%$ das matriculas de nível médio, profissionalizante e EJA (nível médio) no estado, que tem, de acordo com dados do Censo Escolar (2011), um total de 179.584 alunos matriculados nas categorias citadas anteriormente.

Dessa forma, a maioria dos Institutos está em consonância com as potencialidades desses territórios no qual se inserem, uma vez que atendem a alguns critérios da dimensão geográfica da expansão da rede federal. Estes critérios se encaixam, pelo menos, em três dos quais o MEC (2011) pontua como fundamentais: "universalização do atendimento às mesorregiões brasileiras; municípios em microrregiões não atendidas por escolas federais; e por fim, a interiorização da oferta pública de Educação Profissional e Ensino Superior". Nesse sentido, quando inferimos a respeito da expansão dos IF'S em nosso estado observamos que os pontos elencados se aplicam a realidade potiguar. Quanto se trata de planejamento estratégico em nível local, o Estado do Rio Grande do Norte é um dos melhores contemplados, passando por uma das maiores e melhores expansões da educação profissional no Brasil. Para comprovar tal expansão da rede federal, no IFRN, (em tal momento, 2011), por exemplo, o número de alunos em 2004, totalizava 5.000, e em apenas 8 anos, essa estatística passou a somar 34.000 alunos. 
Outra característica interessante de se destacar é o fato de a maioria das cidades do Rio Grande do Norte as quais tiveram Institutos Federais implantados ao território, possuem de certa forma, Arranjos Produtivos Locais - APL's - bem identificados e/ou se encontram no entorno de grandes investimentos governamentais ou privados. Logo, essa ideia entra em acordo com Pacheco (2011, p. 22) a partir da seguinte consideração onde os "Institutos Federais devem explorar as potencialidades de desenvolvimento, a vocação produtiva de seu lócus; a geração e transferência de tecnologias e conhecimentos e a inserção, nesse espaço, da mão de obra qualificada". Deste modo, a distribuição das novas unidades (IFRN'S) pelo maior número possível de mesorregiões e microrregiões, bem como a sintonia com os arranjos produtivos econômicos, sociais e culturais locais vem consolidar a junção entre a educação profissional tecnológica e o desenvolvimento social, local e regional.

O Instituto Federal carrega uma grande gama de influência e de qualidade educacional, Resultando em um impacto claramente observado no cotidiano de uma cidade na qual essa instituição é implantada. E, por isso, mudam-se as feições e reconfiguram-se os territórios, a partir de políticas públicas advindas da chegada de um estabelecimento de ensino desse porte e dos investimentos que o acompanham.

Buscou-se nessa sessão explorar algumas informações acerca da expansão da rede federal de educação tecnológica a nível estadual, ou seja, no Rio Grande do Norte. Percebemos que a ampliação no número de escolas técnicas, Cefet's e Institutos Federais foram gradativos durante os anos, estando interligadas, quase sempre às políticas nacionais de educação. Portanto, podemos salientar que a rede federal de educação no Estado cumpre também uma função social provendo à população uma educação pública de qualidade. Na próxima sessão abordaremos como se deu a implantação do Instituto Federal na cidade de João Câmara/RN.

\section{A IMPLEMENTAÇÃO DO INSTITUTO FEDERAL EM JOÃO CÂMARA/RN}

De acordo com a acepção apresentada por Corrêa (1999), podemos intuir que João Câmara se insere na categoria de "pequenas cidades", as quais o autor também nomeia como pequenos núcleos ou pequenos centros. Ou seja, ele considera inserido nesse grupo, as cidades com população inferior a 50 mil habitantes. Dessa forma, João Câmara que, segundo dados do IBGE (2010), possui 32.227 habitantes, insere-se nessa categoria. Vale salientar que, nesse sentido, a maioria dos Institutos Federais do nosso estado instalaram-se em pequenas cidades, exceto os campi Natal-Central, Natal-Zona Norte, Parnamirim, Mossoró, Ceará Mirim (em construção) e São Gonçalo do Amarante. Os demais, por meio da ação do Estado (representado pelo Ministério da educação) se instalaram nessas aglomerações urbanas as quais tinham economias há anos estagnadas, mas que possuíam certos arranjos produtivos locais como o cooperativismo, a fruticultura, a carcinicultura e outros que tornavam esses municípios com potencialidades propícias a receberem tais investimentos.

Nesse contexto, a construção do Campus de João Câmara fez parte da 2ạ Fase do Plano de Expansão da Rede Federal de Educação Profissional e Tecnológica do Ministério da Educação, iniciada em 2007, constituindo-se em um dos enfoques da atual política do Plano de Desenvolvimento da Educação (PDE) do país. O Estado, dessa maneira, se coloca na realidade local como um agente produtor do espaço urbano com funções reguladoras, legisladoras e organizacionais. Na ótica de Corrêa (1999, p.24) o Estado “[...] atua também na organização 
espacial da cidade. Sua atuação tem sido complexa e variável tanto no tempo como no espaço, refletindo a dinâmica da sociedade da qual é parte constituinte".

Seguindo esse viés, foi gerado um novo processo de valorização no município de João Câmara em que a cidade voltou tanto a ter mais valor quanto atrativos para compradores de terras, comerciantes e investidores da iniciativa privada. Portanto, a ação do Estado no município se deu em duas esferas: a municipal, com a contrapartida do poder público local em dar as condições necessárias para a instalação do Instituto (como melhoria das estradas, sinalização e infraestrutura) e a federal, com a implantação do Instituto na cidade, criação dos cursos e análise da realidade local e com as obras de saneamento básico no município juntamente com a prefeitura municipal. Essas ações coincidiram com o início das obras do IFRN na cidade de João Câmara no final do ano de 2008.

Para que se efetivasse de fato o desenvolvimento socioeconômico, e que se cumprisse a função social pela qual foi criado (promover a educação científico-tecnológico-humanística, visando a formação integral do profissional-cidadão) e proporcionasse uma educação verdadeiramente de qualidade, os Institutos Federais necessitavam conhecer o meio no qual estariam inseridos ou já estão implantados. O objetivo de responder efetivamente aos anseios da sociedade local e os cursos que lá fossem criados estivessem em sintonia com as potencialidades do municipio e da microrregião. Atualmente o campus de João Câmara conta com cerca de 1.500 alunos (sendo 800 do sexo feminino e 700 do masculino) de acordo com dados do SISTEC/IFRN (2012). Consequentemente, grande parte desses alunos tem sua origem nos municípios da região do Mato Grande (Bento Fernandes, Caiçara do Norte, Ceará Mirim, Jandaíra, Jardim de Angicos, João Câmara, Parazinho, Pedra Grande, Poço Branco e São Bento do Norte), Além disso, a renda familiar dos alunos dessa região gira em torno de 3 a 5 salários mínimos, havendo algumas exceções, como os alunos oriundos de João Câmara, que possuem renda familiar de 3 a 5 salários mínimos e 5 a 10 salários mínimos.

O Campus João Câmara está inserido, no planejamento estratégico do desenvolvimento da região do Mato Grande. Atuando com seus cursos, esse Campus já promove a transformação da cidade de João Câmara, e de outras dessa importante microrregião.

Para a escolha dos cursos foi necessária uma consulta à população do município receptor dos Institutos (João Câmara) e dos demais municípios da região do Mato Grande e adjacências. Como nos explica Sônia Cristina Ferreira Maia (2012), diretora geral do campus de João Câmara,

Nós fizemos uma audiência pública pra ver a questão dos eixos tecnológicos, com isso, começamos a divulgar, com mais intensidade, essa instituição pelo território do Mato Grande. Íamos explicando o que era uma educação tecnológica, porque nós tínhamos um perfil diferente da educação do Estado, da educação do município. Explanamos como se dava a entrada aqui como um técnico integrado e como se é o avanço na instituição, no sentido de verticalizar para um ensino superior. Toda essa estrutura metodológica do funcionamento da educação profissional, nós tivemos que explicar e não foi uma situação muito fácil porque, como as pessoas não tinham vivência anterior dessa metodologia.

Outro ponto importante a ser considerado, além das audiências públicas feitas nas cidades, foi à divulgação da instituição. Sônia (2012) explica que "Nós íamos às feiras, às rádios, às escolas, nas ruas, nas praças. Para nós que viemos de uma capital, tivemos dificuldades porque fazíamos 
as divulgações e as pessoas não vinham na instituição" e afirma "Então, nós começamos a perceber que a estratégia que tínhamos usado não era adequada, então começamos a mudar as estratégias de divulgação. Isso tudo foi um aprendizado". É possível concluir, portanto, que mesmo com a implantação do Campus em João Câmara/RN, a população ainda tinha um certo receio em relação à instituição, seja por desconhecimento ou desconfiança de algo novo. Percebendo essa dinâmica, foram necessários novos mecanismos de inserção e divulgação do Instituto nos municípios e respectivos distritos, bem como descreve nossa entrevistada:

Tínhamos duas caminhonetas, fazíamos cartazes e íamos para os municípios e comunidades rurais. Muitas comunidades tinham a dificuldade de não ter internet para os meninos fazerem a inscrição no site. Nós levávamos nossos notebooks com internet móvel para fazermos essas inscrições. Então, tem toda uma cultura diferenciada que nós tivemos que compreender para que pudesse ser divulgada a instituição, nossa educação tecnológica e para que as pessoas acreditassem.

A partir do reconhecimento feito pela população, foram traçadas políticas de ação bem definidas que vêm gradativamente garantindo um ambiente de qualidade para o aprendizado, sempre se adequando às características das cidades, ou seja, valorizando os Arranjos Produtivos Locais (APL's). Segundo Albagli \& Brito (2002, p.6), entende-se os APL's como “um conjunto das unidades produtivas de um mesmo ramo da economia organizado em um território comum, impactando também no âmbito socioeconômico e territorial". No caso de João Câmara especificamente, esses arranjos são a agropecuária, o extrativismo, o cooperativismo e o comércio.

Portanto, seguindo a discussão sobre a respeito dos arranjos, vale reforçar que as instituições de ensino devem prover um conhecimento efetivo e diretamente ligado não só aos APL's, mas também às necessidades sociais e culturais da sociedade em que estão inseridas, promovendo seu desenvolvimento e expandindo seu enfoque. Nesse sentido, os Arranjos Sociais Locais (ASL's) também podem ser entendidos como,

Rede de grupos sociais e atividades características de um território que, integrados aos índices sociais da região, revelam sobre o contexto, o ambiente, as formas de organização e associação, a carência e o desenvolvimento, o nível de inclusão ou exclusão social, a formação social, rural ou urbana, industrial ou comercial, enfim a identidade e a realidade social da região (AMORETTI et al, 2006, p. 6).

Pode-se entender, dessa forma, que as cooperativas, associações de bairros, sindicatos, entidades de base conselhos comunitários fazem parte desses ASL's. Cabe ainda ressaltar os Arranjos Culturais Locais (ACL's) como processos característicos da memória cultural de uma comunidade, sendo assim de importância impar para os estudos de implantação de um Instituto Federal em um município. Podem então ser entendidos como,

\footnotetext{
Aglomerados de unidades de patrimônio histórico material e de patrimônio histórico imaterial, localizadas num mesmo território, criando demandas específicas de mão de obra, articulando a comunidade em torno da identidade cultural de um povo, no sentido religioso, místico e artístico, do patrimônio e da memória cultural, promovendo a articulação de atores locais, tais como comunidade, grupos, associações, instituições religiosas, educacionais, musicais, artesanais e outras. (AMORETTI et al, 2006, p. 5)
} 
Com isso, entendemos que a valorização da cultura local, seja no sentido mercadológico ou cultural, perpassam esse arranjo. Portanto, todos os arranjos acima citados permeiam os municípios onde são implantados os Institutos, no nosso caso a cidade de João Câmara, seus distritos e os municípios localizados em sua área de influência.

O avanço educacional motivado pela expansão da Rede Federal de Educação Tecnológica provocou vários impactos socioeconômicos no município de João Câmara, dentre eles estão: a vinda de pessoas de outras cidades e regiões para estudar no Instituto; a chegada de investimentos privados, como conjuntos residenciais, rede de escolas particulares, o surgimento de cursinhos preparatórios para os processos seletivos do IFRN e vestibular; além desses fatores citados terem potencializado também as atividades terciárias formais (estabelecimentos comerciais, supermercados, mercadinhos, farmácias, restaurantes, pousadas, imóveis para aluguel), e terciárias informais, principalmente no comércio de rua. O pensamento de Romanelli (2005, p.24), nesse contexto, entra em conformidade com o fato de que "[...] a educação escolar tem estado quase sempre em atraso em relação ao desenvolvimento". Isso nos permite concluir que a educação se transforma e se renova ao passo que precisa se adequar aos novos tempos, afim de que não se torne arcaica, bem como se ajustar às novas localidades e especificidades das cidades nas quais estão inseridas. Com isso, o Instituto Federal em João Câmara age e insere-se, assim, na realidade do município, imprimindo desenvolvimento educacional e social através da extensão com a comunidade.

O município torna-se assim, um agente de integração regional e microrregional com outras localidades, pois que exerce uma função polarizadora nos mais variados aspectos e um forte poder de atuação e influência na microrregião de Baixa Verde. Isso ocasionará de certa forma, o provimento de uma educação de qualidade, acompanhada de uma efetiva distribuição de bens e serviços, e o desenvolvimento de atividades terciárias e do comércio, com o IFRN-Campus João Câmara como um dos vetores principais.

\subsection{A implantação dos cursos}

No referido tópico buscaremos fazer um breve panorama do processo e dos fatores motivadores para a implantação dos cursos no campus do IFRN em João Câmara/RN. Para tanto, utilizaremos como base o Plano Político Pedagógico do IFRN, assim como os PPP'S do curso técnico integrado de cooperativismo e do curso de licenciatura plena em física, ambos implantados no Instituto Federal de João Câmara.

Antes de iniciarmos de fato a explanação sobre a implantação dos cursos, devemos rapidamente entender como se contextualiza a inserção das modalidades oferecidas. Como já foi citado anteriormente, entendemos que o IFRN ressalta os aspectos econômicos, sociais, culturais e geográficos dos municípios que recebem os Institutos Federais (no nosso caso João Câmara), com a perspectiva de identificar os arranjos produtivos sociais e culturais de cada microrregião. São também analisados, pois, os aspectos socioeconômicos, que juntamente com outros elementos, como condições pedagógicas, aspectos operacionais e políticos - determinaram a definição das áreas de atuação do IFRN, visando atender assim, às necessidades da população local e regional, no que se refere a formação humana e profissional.

No que compreende à microrregião de Baixa Verde, onde se localiza João Câmara, a população corresponde a 58.936 habitantes, segundo dados do IBGE (2011). Os principais APL'S 
dessa área territorial são a cajucultura, a agricultura, a pecuária, a apicultura, o comércio e a energia eólica. Dessa forma, sendo possível reconhecer que alguns dos cursos, direta (cooperativismo/agricultura, eletrotécnica e energias renováveis) ou indiretamente (informática e licenciatura em física), estão em consonância com as configurações dos arranjos locais.

Formam-se, com isso, têm-se as bases para a elaboração das diretrizes curriculares dos cursos oferecidos no campus, que no caso de João Câmara são nas modalidades PROEJA (Programa Nacional de Integração da Educação Profissional), técnico Integrado e técnico subsequente os cursos técnicos de Cooperativismo - que objetiva a qualificação das pessoas para trabalharem nas diversas cooperativas e assentamentos espalhados por toda a região - e Informática, que tem a função de profissionalizar os alunos para trabalharem nessa área. Além destes, funcionam o curso superior de licenciatura em física, técnico Subsequente em eletrotécnica e o tecnólogo em energias renováveis. A seguir, mostraremos a relação dos cursos oferecidos no Instituto com os arranjos da microrregião.

Quadro 1 - Relação entre os cursos oferecidos no IFRN - campus João Câmara e os arranjos produtivos, sociais e culturais locais

\begin{tabular}{|l|c|c|c|c|c|c|c|}
\cline { 2 - 7 } \multicolumn{1}{c|}{} & \multicolumn{5}{c|}{ APL'S - ASL'S - ACL'S } \\
\hline \multicolumn{1}{c|}{ CURSOS } & Comércio & Ensino & $\begin{array}{l}\text { Energia } \\
\text { eólica }\end{array}$ & Cajucultura & Agricultura & Apicultura & Pecuária \\
\hline $\begin{array}{l}\text { Técnico integrado e subsequente } \\
\text { em Cooperativismo }\end{array}$ & & & & $\mathbf{X}$ & $\mathbf{X}$ & $\mathbf{X}$ & $\mathbf{X}$ \\
\hline $\begin{array}{l}\text { Técnico integrado e subsequente } \\
\text { em Eletrotécnica }\end{array}$ & $\mathbf{X}$ & & $\mathbf{X}$ & & & & \\
\hline $\begin{array}{l}\text { Técnico integrado e subsequente } \\
\text { em Informática }\end{array}$ & $\mathbf{X}$ & $\mathbf{X}$ & & & & & \\
\hline Licenciatura em Física & & $\mathbf{X}$ & & & & & \\
\hline $\begin{array}{l}\text { Tecnologia em Energias } \\
\text { Renováveis }\end{array}$ & & & $\mathbf{X}$ & & & & \\
\hline
\end{tabular}

Fonte: Elaboração do autor.

Com base no quadro 1, observamos como se dá a relação dos cursos oferecidos com os arranjos locais e microrregionais. Notamos que os cinco cursos preenchem, de fato, os setores (arranjos) que se propõem a atender. Em sua maioria são correlacionados com as atividades produtivas e econômicas ou de ensino, dos municípios constituintes da microrregião, como ocorre no caso do curso de cooperativismo que tem uma interlocução com quatro dos sete APL'S (cajucultura, apicultura, pecuária e agricultura), sendo assim, aquele que teoricamente poderá ter ou não uma inserção maior nos territórios dos municípios. Outros dois cursos se inserem também em mais de um arranjo (informática e eletrotécnica), estes além de terem seus vieses comerciais de prestação de serviços, possuem potencialidades no que concerne ao ensino e ao campo da energia eólica, respectivamente. Por fim, os cursos superiores (licenciatura em física e tecnologia em energias renováveis) concentram-se apenas em seus arranjos específicos, que são a área do ensino para o curso de física (uma demanda na rede municipal e estadual de ensino do municipio) e a de energia eólica para o curso de tecnologia em energias renováveis. Feita essa abordagem, analisaremos agora os Planos Políticos Pedagógicos de dois cursos do IFRN de João Câmara: o de cooperativismo e o de tecnologia em energias renováveis. Para tanto, se levará em consideração se o PPP é específico ou genérico, quais são os critérios para a escolha dos cursos, seus objetivos, 
a inserção social e econômica ao território. O quadro 2 representa um panorama de como estão estruturados esses cursos.

Quadro 2 - Comparativo entre os ppp's dos cursos técnico integrado em cooperativismo e tecnologia em energias renováveis

\begin{tabular}{|c|c|c|}
\hline OBJETIVOS & $\begin{array}{l}\text { COOPERATIVISMO } \\
\text { - Geral: } \\
\text { Formar o profissional para atuar na } \\
\text { formação, desenvolvimento e gestão } \\
\text { de } \\
\text { cooperativas da Agroindústria, } \\
\text { planejando e executando os } \\
\text { processos cooperativos nas diversas } \\
\text { áreas de atuação. } \\
\text { - Especificos: } \\
\text { - Desenvolver a formação e o } \\
\text { desenvolvimento de cooperativas, } \\
\text { fundamentado nos princípios éticos e } \\
\text { políticos. } \\
\text { - Atuar na gestão de contratos de } \\
\text { cooperativas, assegurando } \\
\text { cumprimento da legislação } \\
\text { trabalhista. } \\
\text { - Prestar assistência e serviços em } \\
\text { cooperativas, bem como atuar como } \\
\text { fundador de cooperativas imbuído de } \\
\text { um espírito de empreendedor. } \\
\text {-Executar pesquisas } \\
\text { cooperativismo, contribuindo com a } \\
\text { reflexão e ampliação da atuação, dos } \\
\text { princípios e das finalidades do } \\
\text { cooperativismo. }\end{array}$ & $\begin{array}{l}\text { ENERGIAS RENOVAVEIS } \\
\text { - Geral: } \\
\text { Formar profissionais capazes de compreender os } \\
\text { processos de produção, transmissão e distribuição de } \\
\text { energia elétrica através das fontes de energias } \\
\text { renováveis: Eólica, Solar e Hidraúlica e, dessa forma, } \\
\text { realizar atividades de especificação, projeto, } \\
\text { implantação, operação e manutenção de sistemas que } \\
\text { utilizem uma dessas três formas de energia. } \\
\text { - Especificos: } \\
\text { - Formação básica necessária em conteúdos de } \\
\text { Matemática, Física, Línguas, Legislação e Gestão } \\
\text { Empresarial, os quais em conjunto com a capacitação } \\
\text { especifica, poderão atuar na área de energias renováveis } \\
\text { com uma visão sistêmica e multidisciplinar das questões } \\
\text { energéticas e de sustentabilidade. } \\
\text { - Currículo que proporcione desenvolvimento de } \\
\text { habilidades para atuar também em atividades de } \\
\text { pesquisa e extensão voltadas às necessidades do país de } \\
\text { forma competente e ética. } \\
\text { - Meios para impulsionar o aprimoramento de } \\
\text { competências a partir das habilidades desenvolvidas, no } \\
\text { intuito de atuar nos processos de geração, transmissão e } \\
\text { distribuição de energia através de fontes renováveis, } \\
\text { articulando os conhecimentos adquiridos com as } \\
\text { realidades locais e regionais, contribuindo assim para o } \\
\text { seu desenvolvimento. } \\
\text { - Condições para que possam desenvolver uma visão } \\
\text { critica acerca da sociedade brasileira e as diferentes } \\
\text { formas de participação do profissional tecnólogo nesse } \\
\text { contexto, como agente transformador, em prol da } \\
\text { construção de uma sociedade mais justa para todos. }\end{array}$ \\
\hline $\begin{array}{l}\text { INSERÇÃO } \\
\text { SOCIAL }\end{array}$ & $\begin{array}{l}\text { Tem um currículo integrador de } \\
\text { conteúdos do mundo do trabalho e } \\
\text { da prática social do aluno, levando } \\
\text { em conta os saberes de diferentes } \\
\text { áreas do conhecimento. Dessa forma, } \\
\text { busca responder às demandas sociais } \\
\text { e do trabalho, qualificando } \\
\text { profissionais que atendam à } \\
\text { necessidade do mercado emergente } \\
\text { no estado, e, sobretudo, no município } \\
\text { local. }\end{array}$ & $\begin{array}{l}\text { O profissional deve ser capaz de processar informações, } \\
\text { ter senso critico e a capacidade de impulsionar o } \\
\text { desenvolvimento social e econômico da região, } \\
\text { integrando formação técnica a cidadania. Posicionando- } \\
\text { se criticamente e de forma ética frente as inovações } \\
\text { tecnológicas, avaliando seus impactos no } \\
\text { desenvolvimento e na construção da sociedade. }\end{array}$ \\
\hline
\end{tabular}




\begin{tabular}{|l|l|l|l|}
\hline INSERÇÃO & O técnico em cooperativismo & A inserção econômica se dá a partir do momento em que \\
ECONÔMICA & encontra espaço no mercado de & o curso busca atender a crescente demanda por \\
& trabalho local, principalmente na & profissionais qualificados na geração, transmissão e \\
& indústria agropecuária empresas de & distribuição de energia elétrica provenientes de fontes \\
& prestação de serviços, no ramo do & renováveis de energia. Com isso, contribuindo para a \\
& cooperativismo por se tratar de um & elevação da qualidade dos serviços prestados e para o \\
& profissional em condições de criar e & desenvolvimento econômico da região. \\
& viabilizar atividades de & \\
& cooperativismo, tendo em vista a \\
& potencialidade da Região.
\end{tabular}

Fonte: Projeto Político-Pedagógico do IFRN, 2012.

A formação de profissionais capacitados para ingressarem no mercado de trabalho é uma necessidade iminente. Nesse sentido, os cursos técnicos são de grande importância, embora se deva ter o cuidado de associar os PPP's dos cursos às necessidades exigidas pelo mercado, sem deixar de levar em conta os meios e os fins a que são dirigidos. Com base no quadro 2, pretendemos analisar, portanto, a proposta pedagógica dos cursos técnico integrado em Cooperativismo e Tecnologia em energias renováveis do IFRN - Campus João Câmara, associandoa às potencialidades locais.

Ao considerar as especificidades econômicas do município sede do Campus do IFRN, podemos intuir, de início, que os objetivos propostos pelos cursos são condizentes com a necessidade mercadológica, já que há a necessidade de profissionais que estejam aptos tanto para formar, planejar, desenvolver e gerir projetos cooperativos, quanto para implantar, operar e manter sistemas que utilizem energias renováveis. Se avaliarmos os objetivos específicos, seremos influenciados a convir que o curso de cooperativismo é portador de preceitos os quais que se associam à realidade municipal, já que estipulam uma formação que atende às necessidades de uma cidade que se pauta na agroindústria como principal atividade econômica, com base, em grande parte, nos assentamentos da região. Dessa maneira, de acordo com dados do Sistema de Informações de Projetos de Reforma Agrária - SIPRA (2011), esses assentamentos distribuem-se da seguinte forma: Bento Fernandes possui 08 PA's - Projetos de Assentamento - com capacidade para 311 famílias, perdendo em quantidade apenas para o município de João Câmara, que possui 15 PA's com locações para 878 famílias, enquanto Parazinho tem 05 PA's (166 famílias), Jandaíra possui 02 PA's (121 famílias) e por fim, Poço Branco com 05 PA's (121 famílias). Então, concluímos que, por se tratar de um profissional com formação cooperativista, este profissional tem condições de formular, viabilizar e implementar atividades relativas a esse campo de atuação, contribuindo assim para o desenvolvimento econômico e social do município de João Câmara em um primeiro momento, e dos demais municípios da microrregião de Baixa Verde em outro período, haja vista a potencialidade dessas localidades.

O curso de Tecnologia em energias renováveis, por sua vez, apresenta a especificidade de ser implementado no contexto da instalação dos Complexos Eólicos Morro do Vento e Eurus, em João Câmara e Santa Clara, Eurus, Campo dos Ventos, Renascença e Morro dos Ventos em Parazinho. Além disso, devemos considerar que a instalação destes dois parques eólicos compreende um pacote de 62 parques que devem ser instalados em solo potiguar até 2013 . Nesse sentido, podemos entender que as energias renováveis estão recebendo incentivos 
governamentais para sua exploração. Logo, a formação de profissionais que estejam capacitados para lidar com energias renováveis se torna uma necessidade eminente.

Essa especialização sugere, por isso, uma maior possibilidade de absorção de profissionais pelo mercado. No entanto, deve ser pontuado que as possibilidades ainda são pouco diversificadas. Isso implica em um impasse que deve reunir a discussão entre poder público, instituição de ensino, docentes, discentes, sociedade e representantes das vias econômicas. É necessário, não somente, que profissionais estejam capacitados, mas que possam exercer suas aptidões no mundo do trabalho que, por sua vez, deve oferecer condições satisfatórias de trabalho e ascensão profissional. Para tanto, é necessário a junção e a aplicação de esforços comuns que privilegiem o mesmo fim. Caso contrário, técnicos formados pelo IFRN estarão sujeitos a um mundo do trabalho com fronteiras que lhes sufocam e que logo estarão saturadas por não oferecerem, em algum tempo, a demanda de empregos que necessitam os discentes, resultando em profissionais qualificados desempregados ou trabalhando em outras áreas.

Até o presente exposto, é factual ressaltarmos que tanto cooperativismo, quanto tecnologia em energias renováveis são cursos que são formulados com o intuito de atender uma demanda social e econômica. Contudo, ainda é modesto o incentivo que o poder público tem dispensado para o desenvolvimento e manutenção de profissionais capacitados por uma instituição de ensino com a respeitabilidade do IFRN. Além disso, são carentes as medidas integrativas entre os diversos setores da sociedade e as atividades desempenhadas por tais profissionais, podendo gerar a "dispensabilidade" de tais profissionais caso o mundo do trabalho não lhes absorva.

Em suma, os cursos atendem uma necessidade de longa data no município (cooperativismo) e outra insurgente (tecnologia em energias renováveis). Contudo, a instalação de uma instituição de ensino respeitável (IFRN), de cursos técnicos integrados, com a formação de profissionais qualificados e demandas mercadológicas em curto prazo não são os únicos elementos que devem ser levados em conta ao analisar ao analisar os PPPs e as demandas e potencialidades locais. O papel desempenhado pelo poder público municipal e estadual e pela sociedade são critérios de fundamental importância. Na próxima seção, a última do referido estudo, buscaremos discutir e analisar as questões referentes à empregabilidade dos alunos egressos, ou seja, se está havendo a inserção desses alunos no mercado de trabalho, bem como se há estágios em suas respectivas áreas.

\section{FATORES DE DIFICULDADE: A INSERÇÃO DO EGRESSO NO MERCADO DE TRABALHO}

Em um mundo em constante mutação, almejar um espaço para ascensão social e econômica é um desafio, principalmente por observamos que a mudança em ocorrência do desenvolvimento cientifico e tecnológico e com a globalização dos modelos econômicos tem afetado diretamente o mercado de trabalho. Diante dessa perspectiva, a escola vem tendo papel fundamental na formação dos futuros profissionais que se inserirão no mercado de trabalho.

A prática profissional proporcionada pelo estágio e o consequente ingresso no mercado de trabalho após o término de um curso técnico, tecnólogo ou de graduação, geram apreensão no futuro profissional da área escolhida pelo aluno da instituição, no caso do IFRN - João Câmara, isso 
se torna ainda mais pujante, pois mesmo tendo todos os requisitos de um profissional de qualidade, o egresso encontra dificuldades para sua inserção no mercado, onde as oportunidades ainda são poucas. Para entendermos melhor esse processo, vamos focar aqui nos estágios e na empregabilidade após o egresso do curso escolhido especificamente no Campi João Câmara.

\subsection{A prática profissional: o estágio}

O estágio é prática importantíssima na estrutura curricular de qualquer curso, servindo para que o aluno se localize e reconheça sua área de trabalho como futuro campo de atuação e para que, de certa forma, comece a formar sua identidade profissional. O curso, as disciplinas e as experiências adquiridas ao longo do ensino médio técnico, subsequente, tecnólogo e na graduação, tudo isso, deve convergir para o estágio. Nesse sentido, segundo KRUG $(2008$, p.5) o estágio deve ser concebido "[...] como uma experiência, ou seja, como um conjunto de vivências significativas através das quais o estagiário identifica, seleciona, destaca os conhecimentos necessários e válidos para a atividade profissional". Com base na afirmação do autor acima citado, entende-se que a oferta de estágios em João Câmara, bem como na microrregião de Baixa Verde ainda é insuficiente para absorver o grande número de alunos que necessitam dessa prática para sua formação. Poucos são os estabelecimentos, empresas e cooperativas que levam estagiários para a sua localidade de trabalho.

Nesse sentido, em entrevista já citada nesse trabalho, realizada com Sônia Cristina Ferreira Maia, Diretora Geral do Campus do IFRN de João Câmara, no ano de 2012, ela explanou o seguinte,

Nós temos parceiros e também nossos convênios (com a Associação dos Deficientes de João Câmara, com a Associação dos Sindicatos e com as Secretarias de Agricultura). Nós trabalhamos bastante em torno desse convênio através de nosso projeto de pesquisa e de projetos de extensão e, também, com parcerias. Nós temos muitos alunos de cooperativismo estagiando nas secretarias de agricultura e nos sindicatos rurais.

Verificamos, assim, com fundamento na declaração da Diretora Geral do Campus, que de fato existem as parcerias e convênios necessários para que se efetivem os estágios, no entanto, não se vê na prática a inserção dos alunos nessas instituições, com exceção daqueles do curso de cooperativismo (Estarem relacionados mais fortemente com os arranjos produtivos locais), os quais já conseguem oportunidades em secretarias de agricultura, sindicatos rurais e outros órgãos relacionados, bem como os alunos do curso de licenciatura em Física por encontrarem uma série de escolas nas quais conseguem estagiar. Entretanto, como ficam os alunos de outros cursos da instituição? Há oportunidades para eles? Pelo que foi visto são poucas as oportunidades, pois a maioria das "vagas" são destinadas aos estudantes dos cinco municípios da microrregião, com uma ênfase em João Câmara por ter uma gama maior de serviços que podem absorver e fomentar estágios. Em outro trecho da entrevista, Sônia argumentou que "Até o IFRN chegar aqui, a sociedade, as empresas e as instituições não pensavam muito nessa questão do estagiário, de pegar uma mão de obra qualificada. Ou seja, pegavam qualquer um pra fazer qualquer coisa".

É notório que não se ouvia falar realmente em estágios no município polo ou nas cidades circunvizinhas, porém, com a chegada do IFRN, essa gama de influência resultada da instituição, de certa forma impactou localidades, tendo assim, que haver uma readequação territorial para a inserção do Instituto na cidade. Para enriquecer ainda mais a discussão, conversamos com um 
estudante egresso do curso técnico subsequente em informática, que aqui iremos chamar de L.A. Segundo ele, a instituição teve algumas dificuldades

Mediante a grande dificuldade de encontrar estágios, o IFRN (em minha opinião) se viu obrigado a oferecer outros caminhos, daí vem a chance do aluno escolher entre o TCC, projeto de pesquisa ou o estágio, caso encontrasse. E as empresas que tem alguma coisa que se aproveite, não quer pagar o salário instituído por lei para o estagiário.

Um fator relevante e que vem sanando um pouco dessa deficiência em relação ao estágio no IFRN João Câmara, são as bolsas de extensão e pesquisa. Segundo dados do IFRN (2012) existem atualmente 8 bolsistas de extensão (sendo 6 de bolsa institucional - pagas pelo próprio Campus e 2 do Programa Mulheres Mil, o qual é classificado como um projeto de extensão do Campus) e outros 45 bolsistas de pesquisa (sendo 29 do PIBIC/Ensino Médio e 16 do PIBID/IFRN) totalizando dessa forma um total de 53 bolsistas. Contudo, se analisarmos de forma mais criteriosa, iremos constatar que a única modalidade de bolsa que, de certa forma, proporciona uma prática profissional são as de extensão (apesar de serem poucas comparadas às de pesquisa), pois de fato efetivam uma prática mais acentuada em determinada área de atuação a qual a bolsa se direciona, uma vez que, na maioria dos cursos da instituição o estágio não é obrigatório como mecanismo para o aluno concluir o seu curso, podendo-se escolher entre projeto de pesquisa, monografia, projetos de intervenção e o estágio em si.

Portanto, não há uma garantia de estágio para os alunos, sendo poucos os beneficiados pelas vagas disponibilizadas pelas prefeituras e por outras instituições, fazendo com que esse exercício, o qual deveria ser essencial na formação do alunado, deixa de ser fomentado de efetivamente.

\subsection{O aluno egresso e a empregabilidade}

Um dos fatores de maior dificuldade para os estudantes egressos do Instituto Federal localizado no município de João Câmara é a empregabilidade, pois por mais qualificados que os alunos saiam da instituição, o mercado não consegue absorver esses profissionais.

De certa forma, ainda não há uma clara oferta de empregos que venham a absorver essa mão de obra qualificada e oriunda do IFRN, obrigando que o profissional qualificado saia do município para buscar oportunidades de trabalho em sua área de atuação em outras localidades. Se o Instituto havia conseguido frear um pouco do "êxodo educacional" de alunos para a Capital do estado, estes, agora com diploma de nível técnico ou superior, não encontram chances de atuar em um mercado dentro do seu nicho de formação em João Câmara ou na microrregião de Baixa Verde, bem como não conseguem ver perspectivas em sua área de atuação. Vale ressaltar que, o Instituto cumpre o seu papel provendo uma educação realmente de qualidade e com todo o suporte necessário para o aluno desenvolver suas habilidades. Em conversa com o Reitor do Instituto Federal do Rio Grande do Norte, senhor Belchior Rocha, quando perguntado como o IFRN entendia o termo empregabilidade, respondeu:

Para o IFRN a empregabilidade não se restringe a alguém aprender uma profissão através de um Curso Técnico ou Superior de Tecnologia. O nosso projeto aponta para a formação integral, formando o cidadão crítico-reflexivo, capaz de ser 
agente de transformação, não apenas da sua vida, mas de contribuir efetivamente para a transformação de vida de outras pessoas. A empregabilidade para o IFRN passa por uma educação emancipadora, integral e unilateral, a partir da qual a conquista de um emprego será apenas consequência.

A afirmação feita pelo reitor é extremamente válida, no sentido de estar em consonância com aquilo que o Instituto se propõe a cumprir e de fato cumpre. Todavia, mesmo com toda essa carga de formação, principalmente em cidades interioranas (e aqui mais especificamente no caso de João Câmara), o profissional egresso do IFRN, não consegue encontrar o espaço necessário para que possa atuar em sua área e contribuir para o desenvolvimento do seu município. Um fato importante e relativo a essa falta de espaço profissional na cidade foi relatado por outro estudante egresso do curso técnico subsequente em informática, que chamaremos de A.P, para ele os vários cursos têm suas particularidades, porém

No caso de informática, a região em si, deixa muito a desejar no aspecto em que diante de todo o conteúdo adquirido durante o curso o mercado só exija o mínimo. Por exemplo, ao concluir o curso tínhamos conhecimento em Programação, Redes, Banco de Dados e o mercado apenas absorve o conhecimento em Manutenção de Micros, assim deixando uma lacuna onde para que o aluno possa atuar realmente em uma área mais especifica tem que ir buscar fora de nossa região.

Com base na afirmação do aluno podemos constatar o que vem sendo discutido ao longo dessa sessão: há a mão de obra qualificada e pronta para o trabalho, mas não há oferta de qualidade de empresas ou algum órgão público que venha a utilizar o potencial máximo desse profissional local, contribuindo assim, em uma "fuga de cérebros" para Natal/RN.

Outro impasse para a mão de obra egressa qualificada do IFRN é o trabalho com carteira assinada e um piso salarial definido, haja vista que a maioria dos empregos do município de João Câmara é informal, resultou em as empresas e instituições se acomodarem economicamente. Nesse sentido, Sônia argumenta que

Na hora em que lançarmos esses alunos para o mundo do trabalho essa situação vai ter que mudar porque é uma mão de obra qualificada, vai ter que ter registro na carteira de trabalho. Isso tudo não muda do dia para a noite, isso é um processo de conversa, é um processo cultural que vai se alterando no próprio município.

Para isso, os empregadores são levados ao IFRN, onde são realizados fóruns de discussão a fim que se efetivem diálogos entre a sociedade, as tecnologias do mundo do trabalho e com os empresários. Mas, como a diretora geral afirmou, não é uma situação de fácil reversão, todavia é um processo gradual. As oportunidades de emprego existem, contudo não na localidade. Como a mesma afirmou em outro trecho da entrevista "Vieram duas empresas: uma de Natal pegar dois alunos de cooperativismo e dois alunos de energias renováveis e também uma de Recife que veio em busca de 5 alunos de energias renováveis". Ou seja, essas empresas estão indo buscar a mão de obra no interior. Mas será que uma alternativa não seria fomentar a fixação dessas empresas no município?

Então, sob as perspectivas que visualizamos, constata-se que será necessário romper os muros da instituição a fim de dialogar com a sociedade, pois caso contrário, a instituição irá se 
fechar em si, focando apenas em pesquisas, sem atender realmente as necessidades da sociedade. Portanto, não é um processo fácil, empregar uma metodologia para fazer todo esse processo fluir é difícil, porém não é impossível. O maior desafio da instituição, a nosso ver, será o de conseguir fazer com que os profissionais egressos consigam se fixar na microrregião e no municipio receptor do Instituto. Para tanto, dever-se-á integrar políticas públicas educacionais e econômicas federais, estaduais e municipais com o objetivo de mudar esse panorama.

\section{CONCLUSÕES}

O referido trabalho buscou dar uma noção geral do que é, e, como se deu a expansão do Instituto Federal de Educação, Ciência e Tecnologia no Rio Grande do Norte, com ênfase no município de João Câmara, tentando, discutir um pouco da estruturação dos cursos no Campus nesta cidade e suas correlações com os Arranjos Produtivos Locais. Além disso, foi feita uma discussão acerca da empregabilidade, fazendo um paralelo também com a questão do estágio como uma pré-prática profissional. Tal prática como constatamos não é tão fomentada, o que faz com que a formação do aluno seja prejudicada e consequentemente o seu também no mercado de trabalho. Como considerações finais do estudo em tela, buscaremos aqui fazer algumas recomendações, onde procuraremos mostrar caminhos nos quais o município receptor do Instituto (João Câmara/RN) e o governo do Estado possam contribuir para a melhora do quando no que concerne a estágio e empregabilidade.

O poder público municipal de João Câmara, por falta de força política e planejamento a longo prazo, não consegue promover o desenvolvimento municipal e isso se reflete na ausência de novas empresas de pequeno e médio porte no território local, o que poderia ser um fator de alavancamento de estágios e empregos para os alunos egressos do IFRN. Mas o que seria recomendável para mudar esse panorama? A busca de parcerias e convênios se tornariam mecanismos de fundamental importância para a transformação, bem como incentivos fiscais por parte da prefeitura para atrair as empresas. A isenção fiscal de ao menos 1,5\% para as empresas que se fixassem em território camarense também seria viável, pois não prejudicaria as receitas do município, geraria empregos e seria uma alternativa onde os alunos estagiários e egressos do Instituto Federal poderiam buscar oportunidades.

Outro fator importante e que contribui em grande parte para o que foi argumentado acima é a infraestrutura. Nesse sentido, o Governo do Estado do Rio Grande do Norte teria um papel de suma importância no provimento de serviços, como melhoramento das vias de acesso ao município (que hoje tem uma estrutura debilitada). Outra ação que poderia se efetivar seria a melhora da infraestrutura urbana da área, pois poderia receber tais empresas, principalmente na área comercial do município.

Vemos a necessidade de serem organizadas estratégias entre os poderes públicos, cooperativas e o IFRN de forma que ambos possam complementar-se em ações que os engrandeçam, sejam fóruns, congressos, simpósios, feiras de negócios, etc. E essas estratégias devem ser continuas e consistentes para que haja um crescimento educacional-social, crescimento econômico e também das vagas de emprego e estágios.

Temos assim um cenário onde várias políticas públicas estão convergindo no âmbito social, o que confere ao município (João Câmara) uma referência em qualificação profissional (Campi do 
IFRN), atraindo um fluxo crescente de estudantes em busca de formação adequada para o mercado de trabalho. As pessoas retornam às cidades de origem, melhor qualificadas. Será que conseguem com isso induzir transformações na sua realidade local? Provavelmente poucos desses alunos egressos conseguem de fato tal indução, mas a grande maioria ainda é uma incógnita. $E$ tal panorama se expande para outras áreas como o ambiente de negócios dos comércios e órgãos do poder público.

Por fim, vale ressaltar que o IFRN faz sua parte, no que concerne as suas funções de prover uma educação de qualidade. Entretanto, o que se necessita são ações oriundas do poder público municipal que resolvam esses problemas e façam com que a relação do IFRN com a cidade polo de João Câmara seja mais efetiva, homogênea e concreta onde mais grupos sociais tenham acesso às tecnologias, sejam elas de informação ou comunicação, multiplicando as possibilidades de se desenvolver vocações e capacitando e formando profissionalmente cidadãos e alicerçando um mercado que possa absorvê-los. Faz-se a necessidade de lembrar que, de certa forma, faltou um exame mais detalhado da influenciação dependência (em que medida as ações do IFRN em João Câmara dependem de atuações dos poderes públicos municipal e estadual), seja ainda por falta de dados disponíveis dos alunos egressos que ainda é recente (o IFRN está com uma pesquisa a respeito egressos, em andamento, com previsão de término em 2013) ou por falta de dados mais aprofundados de empregabilidade. O esforço no presente trabalho foi o de dar um embasamento para um estudo em futuras pesquisas.

\section{REFERÊNCIAS}

1. ALBAGLI, S. e BRITO, J. Arranjos Produtivos Locais: Uma nova estratégia de ação para o SEBRAE - Glossário de Arranjos Produtivos Locais. RedeSist, 2002.

2. AMORETTI, Juliana et. al. Arranjos Produtivos Culturais e Sociais Locais e a Educação Profissional e Tecnológica. In: I Jornada Nacional de Produção Científica em Educação Profissional e Tecnológica. Março de 2006.

3. BRASIL. Ministério do Trabalho e Emprego. Cadastro Geral de Empregados e Desempregados - CAGED. <http://portal.mte.gov.br/caged/>. Acesso em: 22 de maio de 2012.

4. . Ministério da Educação e Saúde. Legislação Federal. Lei n.o 378, de 13/01/1937. Dispõe sobre a mudança para Liceu Industrial de Natal Disponível em: <http://www6.senado.gov.br/legislacao/ListaPublicacoes.action?id=102716>. Acesso em: 24 de Junho de 2012.

5. . Senado Federal. Legislação Federal. Lei no 11.892, de 29 de dezembro de 2008. Institui a Rede Federal de Educação Profissional, Científica e Tecnológica, cria os Institutos Federais de Educação, Ciência e Tecnologia, e dá outras providências. Disponível em: $<$ http://www6.senado.gov.br/legislacao/>. Acesso em: 15 de Junho de 2012.

6. CORRÊA, Roberto Lobato. O espaço urbano. 3. Ed. São Paulo: Editora Ática S.A, 1999.

7. GIL, A.C. Métodos e Técnicas de Pesquisa Social. São Paulo: Atlas, 1999.

8. instituto bRASILEIRO DE GEOgRAfiA E eStATístiCA. Censo Demográfico de 2010. Disponível em: <http://www.ibge.gov.br/cidadesat/topwindow.htm?1 >. Acesso em: 21 de junho 2012. 
9. INSTITUTO FEDERAL DE EDUCAÇÃO, CIÊNCIA E TECNOLOGIA DO RIO GRANDE DO NORTE (IFRN). Projeto Político-Pedagógico do IFRN: uma construção coletiva. Natal, 2012.

10. INSTITUTO NACIONAL DE ESTUDOS E PESQUISAS EDUCACIONAIS ANISIO TEIXEIRA. Censo Escolar de 2011: Disponível em: <http://www.educacao.rn.gov.br/contentproducao/aplicacao/seec/aplicativos/enviados/ma tricula.asp>. Acesso em: 9 de Julho de 2012.

11. JÚNIOR, Mauricio Gaciba; AZEVEDO, Luiz Alberto; COAN, Marival. Os Institutos Federais e os Arranjos Produtivos: um estudo de caso do layout do Instituto Federal de Educação, Ciência e Tecnologia de Santa Catarina (IFSC). In: Caderno de Teses da 26a CONSINASEFE. Brasília, Março/Abril de 2012.

12. KRUG, Hugo Norberto et al. "Estágio Curricular supervisionado em Educação Física: significado e importância sob a ótica dos acadêmicos do curso de licenciatura". Grupo de Estudos e Pesquisas em Educação Física (GEPEF/UFSM); apresentado no XXVII Simpósio Nacional de Educação Física, Pelotas - RS, 2008.

13. MAIA, Sônia Cristina Ferreira. Entrevista com Gestor. João Câmara, IFRN-Campus João Câmara, 29 de Julho de 2012. Entrevista a Marcio Barreto.

14. OLIVEIRA, Christian Dennis Monteiro de. Terciarização e espaço metropolitano. Revista Boletim Paulista de Geografia, São Paulo, n. 65, p. 49-77, jul./dez. 1987.

15. PACHECO, Eliezer. Institutos federais: uma revolução na educação profissional e tecnológica. São Paulo: Moderna, 2011.

16. ROCHA, Belchior. Entrevista com o Reitor. Natal, IFRN - Campus Central, 25 de Setembro de 2012. Entrevista a Marcio Barreto.

17. ROMANELLI, Otaíza de Oliveira. História da Educação no Brasil. 29. Ed. Petrópolis: Vozes, 2005.

18. SANTOS, Leonardo Araújo. Entrevista com o estudante. João Câmara, IFRN-Campus João Câmara. 15 de Agosto de 2012. Entrevista a Marcio Barreto.

19. SOUZA E SILVA, Rômulo Jarson. Perfil sócio-demográfico do município de João Câmara 1940 - 2000. UFRN/Natal, 2006. 